\title{
Discussion Paper Climate Change and Consumer Finance: A Very Brief Literature Review
}

José J. Canals-Cerdá

Federal Reserve Bank of Philadelphia

Supervision, Regulation, and Credit Department

\section{Raluca A. Roman}

Federal Reserve Bank of Philadelphia

Supervision, Regulation, and Credit Department
DP 21-04

October 2021

https://doi.org/10.21799/frbp.dp.2021.04 


\title{
Climate Change and Consumer Finance:
}

\section{A Very Brief Literature Review ${ }^{1}$}

\author{
José J. Canals-Cerdá \\ Supervision, Regulation, and Credit Department \\ Federal Reserve Bank of Philadelphia \\ Raluca A. Roman \\ Supervision, Regulation, and Credit Department \\ Federal Reserve Bank of Philadelphia
}

\begin{abstract}
Extant research shows that climate change can impose significant costs on consumers' wealth and finances. Both sea-level rise and flooding from hurricane events led to high price declines and thus wealth loss for homes in coastal areas or in disaster-struck areas, with effects lingering for a number of years in some cases. In terms of consumer finance, while the average consumer is not always significantly negatively affected by a disaster, the vulnerable groups (those with low credit scores and who are low income) can be severely affected, experiencing higher rates of delinquencies and bankruptcies in the aftermath. Banks help mitigate the negative effects in highly impacted areas by increasing their supply of credit, with more beneficial effects found among small and local lenders. Finally, the impacts of natural disasters and climate change on consumer finance can be further influenced by factors such as government assistance and insurance, which can both improve outcomes and induce moral hazard. We caution, however, that evidence reviewed here may be incomplete and calls for further work on all these important issues.
\end{abstract}

Keywords: climate change, natural disasters, sea-level rise, consumer finance, house prices, consumer delinquency, consumer credit, government assistance

JEL Codes: D10, D14, G50, Q50, Q54, R21, R31

\footnotetext{
${ }^{1}$ Authors: José J. Canals-Cerdá, senior special advisor, and Raluca A. Roman, senior economist, at the Federal Reserve Bank of Philadelphia.

Disclaimer: This Philadelphia Fed Discussion Paper represents preliminary research that is being circulated for discussion purposes. The views expressed in these papers are solely those of the authors and do not necessarily reflect the views of the Federal Reserve Bank of Philadelphia or the Federal Reserve System. Nothing in the text should be construed as an endorsement of any organization or its products or services. No statements here should be treated as legal advice. Any errors or omissions are the responsibility of the authors. Philadelphia Fed Discussion Papers are free to download at https://philadelphiafed.org/consumer-finance-institute/publications.
} 


\section{Introduction}

There is evidence that climate change from increasing levels of carbon dioxide poses significant risks for both the U.S. and global economy (e.g., Ackerman and Stanton, 2008a, 2012; Ackerman, Stanton, Hope, and Alberth, 2009; Ackerman et al., 2008b; Hansen, Ruedy, Sato, and Lo, 2010; Burke, Hsiang, and Miguel, 2015; NASA Earth Observatory, 2017; NOAA, 2017; Hilmi, TheuxLowen, and Pinochet, 2020; UN IPCC, 2021; Brainard, 2021). ${ }^{2}$ Extreme weather events such as hurricanes and flooding, wildfires, sea-level rise, and heat waves impact human lives and health, and induce property and other asset losses, while mitigation and adaptation actions can contribute to lower potential future losses. The most recent 2021 report from the U.N. on the climate crisis is viewed as "a code red for humanity" (U.N. Secretary-General António Guterres) as "widespread and rapid changes have already occurred," affecting all regions on Earth, with many changes being impossible to reverse. ${ }^{3}$ A report by Munich RE (2018) finds that natural disasters have resulted in more than $\$ 5.2$ trillion in losses globally since 1980, more than 70 percent of which were not insured. ${ }^{4}$ Another report issued by 13 U.S. federal agencies in 2018 predicted that the potential damage from the consequences of climate change could result in as much as a 10 percent reduction in the size of the U.S. economy by the end of the century. ${ }^{5}$

With climate risks rising, governments are forming alliances to adapt and combat the effects of climate change, and regulators are mobilizing to support these efforts and to ascertain financial institution risk sensitivities and management strategies for climate change. One notable event is the Paris Agreement announced on December 12, 2015, under which signing countries (191 countries plus the European Union) agreed to take actions to limit global temperature rise in this century to 1.5 degrees Celsius above preindustrial levels and to report regularly on their emissions and on their implementation efforts to achieve the goal. ${ }^{6}$

\footnotetext{
${ }^{2}$ See https://www.ipcc.ch/report/ar6/wg1/; https://www.federalreserve.gov/newsevents/speech/brainard20210218a.htm.

${ }^{3}$ See https://www.cnn.com/2021/08/09/world/global-climate-change-report-un-ipcc/index.html.

${ }^{4}$ See https://www.munichre.com/en/risks/natural-disasters-losses-are-trending-upwards.html.

${ }^{5}$ See https://www.nytimes.com/2018/11/23/climate/us-climate-report.html.

${ }^{6}$ See https://www.un.org/en/climatechange/paris-agreement.
} 
While it is difficult and ambiguous to assess the costs of the climate change ex ante, we can learn valuable lessons by evaluating the effects of past climate events on the financial lives and wealth of economic agents. In addition to the direct effects, impacts also refer to mitigation efforts to prevent the future negative consequences of climate change as well as adaptation efforts, such as climate risk management, to adjust and better control risks once they arise.

This Discussion Paper focuses on the literature exploring the impact of climate related natural events on consumer finance. We review the effects of sea-level rise (SLR) on home prices, effects of flooding on home prices, effects of various climate-related natural events on consumer finance overall and for the less affluent, as well as how banks respond to these events. Finally, we look at government assistance and insurance as potential mitigants to household financial distress. We reference a significant number of papers, acknowledging that it is impossible to keep up with all the relevant research that is continuously evolving.

\section{Climate Change: Economic and Financial Impact on Consumers}

\section{Sea-level rise and home prices}

One widely studied aspect of climate change in the economic literature refers to the impact of SLR expectations on current home prices. This is not surprising, considering the potential consequences of SLR on housing stock, while also considering the significant uncertainty surrounding SLR estimates. ${ }^{7}$ Studies can be broadly categorized into different research. There are studies that address the question of the price effect of SLR directly, like the recent work by Bernstein, Gustafson, and Lewis (2020). ${ }^{8}$ Other studies such as Ortega and Taspinar (2018) address the related question of the impact of natural disasters on property values. The focus of these studies is often both on properties damaged in the natural disaster and on nondamaged properties exposed to SLR risk or flood zone properties that may suffer a potential price penalty

\footnotetext{
${ }^{7}$ See IPCC (2013) for a widely publicized report on a broad range of timing and magnitude of SLR, available at https://www.ipcc.ch/site/assets/uploads/2018/03/WG1AR5 SummaryVolume FINAL.pdf.

${ }^{8}$ Other relevant works include Baldauf, Garlappi, and Yannelis (2020); Keys and Mulder (2020); Murfin and Spiegel (2020); Atreya and Czajkowski (2019); and Hino and Burke (2020).
} 
as well. ${ }^{9}$ The empirical design across studies varies by data source, time horizon, and other design features but otherwise has many conceptual similarities. Estimates of the direct price effect of SLR vary widely across studies.

Without delving into technical details, studies compare prices of SLR-exposed houses compared with otherwise observationally equivalent non-SLR-exposed houses. Bernstein, Gustafson, and Lewis (2020), using data from the period 2007-2016, find that homes exposed to SLR face a 7 percent average price penalty. This penalty has increased in recent years and by the level of SLR exposure, with the penalty growing to 14.7 percent for properties inundated with two to three feet of SLR and for sophisticated buyers and communities worried about global warming. Baldauf, Garlappi, and Yannelis (2020) find that houses projected to be underwater in neighborhoods with a higher proportion of climate-change believers sell at a discount compared with houses in neighborhoods with more skeptics of climate consequences. In contrast, Murfin and Spiegel (2019), using data from coastal home sales, find limited price effects of SLR. ${ }^{10}$ Athreya and Czjkowski (2019), using data from a coastal county in Texas, find that properties located in the highest flood risk area actually command a price premium.

So far, a consensus view on the impact of SLR on home prices has yet to emerge. Differences in empirical research design may partially explain observed differences in findings across studies. Furthermore, the complex impacts of SLR on home prices have the potential to change over time in response to changes in SLR projections, changes in societal perceptions, knowledge acquisition, government policies, and SLR remediation efforts. Additional research that attempts to reconcile findings should be particularly valuable.

\footnotetext{
${ }^{9}$ Other relevant works include Vigdor (2008); Dillon-Merrilly, Gez, and Getex (2018); and Cohen, Barr, and Kim (2021).

${ }^{10}$ In related work, Keys and Mulder (2020) note that most-SLR-exposed communities in the coastal Florida market have appreciated at a slower pace in recent years, and home sale volumes have also declined. Hino and Burke (2020) measure the effect of information about flood risks in the universe of U.S. homes and find little evidence that housing markets fully price information about flood risk in aggregate.
} 


\section{Flooding on home prices}

In addition to SLR, hurricanes and flooding are other extreme weather natural disasters impacting consumers and consumer wealth. The impact of hurricanes and ensuing floods on home prices can be difficult to forecast ex ante. Researchers often use hedonic valuation models to show that home sale prices can capitalize property risk factors, such as flood zones, for properties with higher flood risk selling at a discount.

Ortega and Taspinar (2018) analyze the effects of Hurricane Sandy on the New York City housing market and document a significant negative impact on home prices in the hurricane's aftermath. They find a 17 percent to 22 percent price decline instantly after the storm for damaged properties and a price penalty as high as 8 percent for nondamaged flood zone properties, consistent with an increased perceived risk of large-scale flooding incidents in that area.

Fang, Li, and Yavas (2020) use residential transaction data from Miami, FL, and find that the impact of a property's flood risk exposure on its value changes over time, having a price penalty of 4 percent in the hurricane striking period. Conversely, during a tranquil hurricane period, properties in high-flood hazard zones demand a price premium ranging roughly from 4 percent to 6 percent, which may represent the price impact of water-related amenities. The premium declined significantly once Hurricane Sandy hit. The authors surmise that the occurrence of a hazardous hurricane, which impacted distant regions, also raised local home buyers' perception of flood risk, but only for a short period of time (one quarter).

Atreya, Ferreira, and Kriesel (2013) use property sales data from a county in Georgia and find that, after "the flood of the century" in 1994, prices of properties in the 100-year floodplain fell significantly, but this effect was relatively short lived. They find that flood risk discount vanished between four and nine years after the flood. Bin and Landry (2013) use data for a county in North Carolina accounting for many storm events and find that prior to Hurricane Fran in 1996, there is no market risk premium for a home in a flood zone. However, the authors find significant price differentials after major flooding events in these areas, leading to a 5.7 percent price decrease after Hurricane Fran and an 8.8 percent price decrease after Hurricane Floyd. Results from a different model using more recent data without significant storm-related flood events 
show a significant risk premium ranging between 6.0 percent and 20.2 percent for homes sold in a flood zone, but this effect is decreasing over time, vanishing about five or six years after Hurricane Floyd.

Finally, Gibson, Mullins, and Hill (2019) estimate the price effects of three flood risk signals: 1) the Biggert-Waters Flood Insurance Reform Act, which raised price premiums; 2) Hurricane Sandy; and 3) new floodplain maps reflecting three decades of climate change. Estimates are negative for all three signals, and some are large in magnitude. For example, properties included in the new floodplain after flooding by Hurricane Sandy experienced 18 percent price reductions. Harrison, Smersh, and Schwartz (2001) and Zhang (2016) also find that homes with comparable characteristics located in a flood zone sell on average for less than homes outside flood zones, with the lower-priced houses being most adversely affected.

While all these studies suggest negative effects on house prices from flooding, there is a lack of persistent effect. This may suggest that buyers' and sellers' risk perceptions change with the incidence of events or their personal beliefs about climate change (see, e.g., Baldauf, Garlappi, and Yannelis, 2020, suggesting that house prices reflect heterogeneity in beliefs about long-run climate change risks). It can also suggest that some home buyers and sellers lack understanding of flood risks and/or insurance requirements for these houses (e.g., Chivers and Flores, 2002; Atreya and Ferreira, 2015; Hino and Burke, 2020). ${ }^{11}$

In contrast to studies discussed previously, one paper finds that flood risk can also drive up house prices. Vidgor (2008) finds that Hurricane Katrina resulted in a 50 percent decline in the number of housing units in New Orleans between 2000 and 2006, and the reduction in supply of housing exceeded the reduction in demand. Therefore, home prices in New Orleans rose dramatically in the aftermath of Hurricane Katrina.

Thus, almost all extant research points toward flood risks driving home prices down and price differentials reflecting flood risk as much larger in the wake of large events. However, events like Hurricane Katrina can generate significant supply-and-demand disruptions in housing and labor markets that can make the impact of specific events difficult to predict.

\footnotetext{
${ }^{11}$ Bakkensen and Barrage (2018) find that the U.S. market for coastal homes over 2007-2016 surpassed fundamental values by 10 percent because the market did not fully control for flood risk.
} 


\section{Climate change impact on consumer finance (credit score, delinquency, default, debt levels, and income)}

Research on the impacts of natural disasters (fires, hurricanes and floods, SLR, etc.) on personal finances is more scarce. Natural disasters can result in large property destruction, personal injury, and loss of human life. From a financial perspective, natural disasters can result in major negative shocks to household finances because of large, unexpected expenses driven by damaged or destroyed homes, work disruptions, and health and other problems. Recent studies delve into the impact of natural disasters on personal income and financial well-being.

Groen, Kutzbach, and Polivka (2016) analyze employment and earnings growth associated with Hurricanes Katrina and Rita. Earnings are reduced in the first year after the storm, but three years after the storm, earnings of affected individuals outpace earnings in the control group. The recovery in earnings was not homogeneous across sectors, with sectors related to rebuilding experiencing wage growth and sectors closely tied to tourism experiencing net earnings losses. Deryugina, Kawano, and Levitt (2018) also find that the impact of Hurricane Katrina on employment and the income of impacted individuals and victims' incomes surpassed that of the control group within just a few years. Also consistent with prior research, the authors find large and persistent impacts on where people live. Farrell and Greig (2018) analyze the impact of Hurricanes Harvey and Irma on checking account activity and observe a reduction in inflows and outflows of funds, but the effects do not last for more than a couple of weeks.

Some studies focus directly on the impact of climate-change risk on consumer delinquency, foreclosure, and default. Issler, Stanton, Vergara-Alert, and Wallace (2020) study wildfires in California between 2000 and 2018 and their effects on consumers. They find significant increases in mortgage delinquency and foreclosures after fires, but the impact is inversely correlated with the size of the fire, which the authors argue is due to coordination externalities from large fires where vast tracks of homes are replaced by modern structures that meet current building codes. Billings, Gallagher, and Ricketts (2021) model ex-post default outcomes of mortgages on homes damaged by floods from Hurricane Harvey, which hit Houston in August 2017. They find that 28 percent fewer Small Business Administration (SBA) loan dollars 
went to neighborhoods where residents qualified but had a more limited ability to repay an SBA loan. They also found that heavy flooding increased the bankruptcy rate in these same areas by 1.4 percentage points (or 39 percent), relative to similar areas that did not flood; delinquency showed a similar pattern. In contrast, flood victims with the highest likelihood of being approved for an SBA loan observed a relatively small decrease in their delinquent debt after flooding, consistent with the SBA loans acting as a liquidity smoothing mechanism.

Ratcliffe, Congdon, Teles, Stanczyk, and Martin (2020) observe that medium-size natural disasters are less likely to receive long-term government recovery funds, and hence, they result in larger declines in household credit scores. Kousky, Palim, and Pan (2020) use Hurricane Harvey to examine the link among property damage, flood insurance, and mortgage credit risk. They find that compared with homes without damage, mortgages on moderately to severely damaged homes were more likely to become delinquent shortly after Hurricane Harvey.

A study by JPMorgan Chase Institute (2018) uses transaction-level data from over 1 million checking account holders to look at the impacts of Hurricanes Harvey and Irma on consumer financial outcomes. They find that checking account inflows fall 20 percent and outflows by more than 30 percent after a natural disaster. The changes in spending result in significant welfare losses for some families. ${ }^{12}$ Roth Tran and Sheldon (2019) find that consumers increase their credit card use after a disaster to smooth the shock, but overall consumer credit outcomes for individuals residing in areas affected by natural disasters do not appear to be significantly impacted by the disasters, except for some vulnerable consumers, which we discuss in next section. Gallagher and Hartley (2017) study the effects of Hurricane Katrina and find that surges in credit card borrowing and overall delinquency rates for residents with the most flooding are small and short lived. They also find larger reductions in total debt, driven by homeowners using flood insurance to repay their mortgages rather than to rebuild.

Thus, the evidence suggests that natural disasters can have a significant impact on credit scores, delinquency, default, and personal income. However, the negative impact of natural disasters on household income may be relatively short lived in some but not all cases.

\footnotetext{
${ }^{12}$ See www.jpmorganchase.com/corporate/institute/report-weathering-the-storm.htm.
} 
Government assistance and insurance can play a significant role on the evolution of consumer finance after a natural disaster.

\section{Natural disaster and the less affluent}

Climate change and natural disasters have disparate effects on individuals and households. Evidence on the impact of natural disasters on financial well-being suggests that consumers in a fragile financial position prior to the natural disaster may be more likely to be more financially impacted by it.

Roth Trans and Sheldon (2019) find that, although overall consumer credit outcomes for individuals residing in disaster-affected areas are not significantly impacted by the disasters, vulnerable consumers do experience worse outcomes. Subprime individuals with the lowest credit scores and those in low-income neighborhoods affected by disasters and without access to individual aid are more likely to have bankcard payments past due and to declare bankruptcy after disasters. Sheldon, Gall, and Collins (2017) also find that lower-income households tend to lose more wages after disasters, possibly because they are more likely to earn hourly wages and have less ability to work from home.

Similarly, Ratcliffe, Congdon, Teles, Stanczyk, and Martin (2020) find that a natural disaster reduces credit scores of impacted residents and increases mortgage delinquencies and foreclosures. Furthermore, estimated declines in credit score are particularly substantial for those with low scores prior to the disaster and for those who live in minority communities. Billings, Gallagher, and Ricketts (2021) analyze the impact of Hurricane Harvey on financial wellbeing and homeownership status. Similarly, they find that the negative financial impact is focused among homeowners who entered the hurricane in a weaker financial position. Ratnadiwakara and Venugopal (2020) document that areas affected by major flooding disasters attract less affluent and less creditworthy homebuyers resulting in de-gentrification of at-risk neighborhoods.

Thus, economic research points to a disparate effect of natural disasters on the less affluent. The results from these studies highlight the importance of aid to help vulnerable households weather disasters and suggest that the expansion of government programs such as 
the Federal Emergency Management Administration (FEMA) financial assistance could help stabilize these at-risk households.

\section{Natural disasters and bank lending}

A smaller body of literature investigates how banks help address climate-change concerns such as extreme weather events by helping recovery efforts. Governments and financial institutions tend to offer assistance that often includes both payment and credit relief for customers affected by natural disasters. ${ }^{13,14}$

Cortés and Strahan (2017) track disasters between 2001 and 2010, which induce exogenous increases in local credit demand (driven by increased need to rebuild destroyed or damaged properties and other assets), and test how these increases in demand affect lending in other markets connected to banks exposed to the shocks. Using mortgage origination data, the authors document that banks reallocate funds toward markets with high-credit demand in which they own branches and away from other markets (connected markets) in which they lend. Thus, credit seems to flow toward high-demand markets and away from lower-demand ones. They find that this is driven by small banks, defined as those with assets below \$2 billion. Also, credit supplied to connected markets declines by a little less than 50 cents per dollar of increased lending in their shocked areas. In contrast, larger banks do not reduce credit in connected markets, most likely because of lower external financing costs. Moreover, small banks increase sales of more liquid, smaller mortgage loans and increase deposit rates in the connected markets to help lessen the impact of the demand shock on credit supply. ${ }^{15}$ Gallagher and Hartley (2017) find that areas flooded by Katrina that had a larger presence of local banks registered higher lending growth, consistent with local banks encouraging rebuilding. Cortés (2014) finds that areas

\footnotetext{
13 The Federal Emergency Management Administration (FEMA) offers government relief for consumers suffering from natural disasters; see https://www.fema.gov/assistance/individual. Using data on U.S. hurricane landfalls from 1979 to 2002 , Deryugina (2017) finds that government disaster aid averaged around $\$ 160$ per capita, while nondisaster social insurance transfers increased around $\$ 1,000$ per capita in the disaster areas over the 10 years following the hurricane.

${ }^{14}$ Regulators often encourage banks to lend to disaster-struck areas. Credit relief can take the form of restructuring existing loans, extending repayment periods, or providing new credit at more favorable terms to the consumer.

${ }^{15}$ Focusing on payday lenders rather than banks, Morse (2011) finds that poor residents fare better across a number of outcomes following natural disasters in areas served by payday lenders.
} 
with a greater relative presence of local lenders recover faster after disasters. An increase in local finance offsets the negative effects of the disaster and can lead to 1 percent to 2 percent higher employment growth at younger and smaller firms. Banks' increased lending in disaster areas does not result in higher default rates. ${ }^{16}$

Chavaz (2016) shows that banks with a higher concentration in markets hit by the 2005 hurricane season (specifically Hurricanes Katrina, Rita, Wilma, and Dennis) increased lending more than banks with a lower concentration in those areas. Compared with diversified banks, local banks originate a higher share of new mortgages and small business loans in affected areas but sell a higher share of the new mortgages to the secondary market. These results suggest a potential bank specialization, under which loans in affected areas are originated more by banks with incentives to take opportunities in a distressed market, but then get them transferred to agents that can better support the associated risk. In a similar vein, Kahn and Ouazad (2019) find a substantial increase in bank mortgage securitization activity in the years following natural disasters, with the effects larger in areas where the disaster was "new news." This suggests that bank lenders have incentives to securitize loans with higher flood risks to mitigate credit risks.

Finally, Lambert, Noth, and Schuwer (2019) explore how banks reacted to Hurricane Katrina in 2005 and what the effects of banks' involvement were on local economic development. Stand-alone banks (not owned by a bank holding company) based in the disaster areas increased their risk-based capital ratios after the hurricane, while those that are not part of a bank holding company generally do not. In addition, affected counties with a relatively large share of standalone banks and relatively high-average bank capital ratios show higher economic growth than other affected counties following the catastrophic event.

Cheney and Rhine (2006) analyze the U.S. financial system's response to Hurricane Katrina and the safety nets in place for disaster-area residents. They emphasize the significant disruptions to local banking networks, and simple financial transactions, resulting from damage to physical infrastructure and the lack of electric power in the area. They also document the extraordinary measures taken by financial institutions and regulators to increase the flow of

\footnotetext{
${ }^{16}$ Focusing on earthquakes, Garmaise and Moskowitz (2009) find that earthquake risk decreased commercial real estate bank loan provision by 22 percent in California properties in the 1990s, with more severe effects in African American neighborhoods.
} 
credit and financial relief. The paper also highlights the importance of preparedness and contingency planning on the part of financial institutions and the government to serve the public at the time of a natural disaster. Their research indicates that consumers who hold deposit accounts at financial institutions are less vulnerable to financial disruption than the unbanked. The authors emphasize the importance of novel forms of providing financial assistance, prepaid and electronic benefit transfer cards in particular, that can reach the most vulnerable population, which concentrates a significant percentage of unbanked individuals. Some of the lessons highlighted in their paper may not directly translate today, given the preponderance of wireless communications and novel methods of payments, but their main lessons likely remain valid today. Specifically, preparedness, contingency planning, and the use of payment technology or combination of technologies provide banking services and financial relief to people in need and the best combination of resiliency, speed and reach, while safeguarding the integrity of the system. ${ }^{17}$

Thus, economic research indicates that banks help mitigate the negative effects of natural disasters in highly impacted areas by increasing the provision of loans while protecting themselves by securitization of high-risk loans and increasing their capital base. Increased credit in impacted areas contributes to higher employment growth at younger and smaller firms. Thus, financial institutions also tend to offer financial relief to customers affected by natural disasters.

\section{Natural disaster: government assistance, insurance, and adaptation}

The effects of natural disasters and climate change on consumer finance are significantly impacted by factors such as government assistance and insurance in the short run and preventive measures of adaptation like infrastructure investments and changes in zoning plans in the longer run.

The literature provides ample evidence supporting the significant impact of insurance in periods of natural disasters. Kousky, Palim, and Pan (2020) analyze the impact of Hurricane

\footnotetext{
${ }^{17}$ On May 3 and 4, 2006, the Payment Cards Center at the Philadelphia Fed hosted a conference to address these issues titled "The Role of Electronic Payments in Disaster Recovery: Providing More Than Convenience." See Cheney (2006) for details.
} 
Harvey and document that in areas where very few borrowers have flood insurance, as property damage increases, the likelihood of needing a loan modification increases and the probability of mortgage default within two years also increases significantly. Looking at the impact of mandates, areas where borrowers are required to have flood insurance experience improved credit outcomes in the long run. However, in areas where flood insurance is not required and very few borrowers have flood insurance, property damage increases, and the likelihood of needing a loan modification increases, along with the likelihood of a loan being delinquent or in default during the two years following Hurricane Harvey. Billings, Gallagher, and Ricketts (2021) also using data from Hurricane Harvey similarly document that flood insurance largely mitigates the negative effect of the natural disaster. Ratcliffe, Congdon, Teles, Stanczyk, and Martin (2020) observe that medium-size natural disasters are less likely to result in long-term government recovery funds, and this results in larger declines in consumer credit scores than larger disasters.

While the previous paragraphs highlight the positive impact of insurance on financial outcomes after a natural disaster, there is also an extensive literature highlighting the shortcomings of government insurance and assistance programs. On the one hand, researchers highlight concerns about the sound actuarial foundation and pricing of government-sponsored flood insurance programs (Michel-Kerjan, 2010; Knowles and Kunreuther, 2014; Brannon and Blask, 2017). On the other hand, flood insurance, like other forms of insurance, is subject to potential moral hazard. That is, the availability of this type of insurance may incentivize potential risky behavior by economic agents. Specifically, some authors are concerned that potential mispricing of flood insurance may not provide a sufficient disincentive to invest in flood-prone areas, although the evidence is mixed (Dehring, Lastrapes, Eckles, and Browne, 2014; Peralta and Scott, 2019). Climate change may increase the risk of extreme events and put additional stress on government insurance programs (van der Wiel, Kapnick; van Oldenborgh, Whan, Philip, Vecchi, Singh, Arrighi, and Cullen, 2017). Thus, continued research and debate on these topics is an important priority.

Finally, adaptation to climate change can take many forms; new technologies and infrastructure investment first come to mind. The well-researched forms of financial adaptation previously discussed are flood insurance and government assistance. But other novel forms of 
financial innovations may also mitigate the risks of climate change. Adaptation through financial innovation - such as sustainable financial instruments - can also contribute significantly to mitigate the challenges of climate change and its consequences. ${ }^{18}$

The findings from the literature highlight the importance of government assistance and flood insurance in protecting homeowners and mortgage creditors against credit risk and on improving consumer finance outcomes ex post, but moral hazard consequences are also possible. Financial innovation may contribute new tools to important financial adaptation to climate change.

\section{Concluding remarks}

Overall, the extant research reviewed in this Discussion Paper shows that climate change can impose costs on consumer wealth and finances. Both SLR and flooding from hurricanes appear to decrease home prices in coastal or disaster-struck areas, implying wealth loss, and some of these effects last for years in some cases. With regard to finances, consumers use more credit after natural disasters to smooth out the shocks. Although the average consumer is not always negatively impacted by disasters because of a more solid financial position ex ante, the most vulnerable consumers (those with low credit scores and low incomes) are often severely affected, experiencing a loss of income and higher delinquencies and bankruptcies in the aftermath. Banks tend to alleviate these effects in highly impacted markets by providing more loans, while more beneficial effects are found among small and local lenders. However, banks do protect themselves from credit risk by using securitization of risky loans and increasing their capital ratios. Finally, the relationship between natural disasters and consumer finance can be moderated by factors such as government assistance and insurance, suggesting that these factors play key roles in improving consumer outcomes after disasters. We caution, however, that this evidence may be incomplete, and we look forward to more research on all these critical issues to expand our understanding. Future research may tackle aspects of financial innovation for climate

\footnotetext{
${ }^{18}$ Recent work by Engle, Giglio, Kelly, Lee, and Stroebel (2019) represents a recent example of adaptation to climate change through financial innovation.
} 
change and estimate whether efforts to reduce carbon emissions and mitigate extreme weather events and SLR can have a positive impact on consumer finance. 


\section{References}

Ackerman, F., and E. A. Stanton. (2008a). "The Cost of Climate Change: What We'll Pay If Global Warming Continues Unchecked." Natural Resources Defense Council Working Paper.

Ackerman, F., and E. A. Stanton. (2012). "Climate Risks and Carbon Prices: Revising the Social Cost of Carbon." Economics 6(1).

Ackerman, F., E. A. Stanton, C. Hope, and S. Alberth. (2009). "Did the Stern Review Underestimate US and Global Climate Damages?" Energy Policy 37: 2717-2721.

Ackerman, F., E. A. Stanton, C. Hope, S. Alberth, J. Fisher, B. Biewald, and S. Economics. (2008b). "Climate Change and the US Economy: The Costs of Inaction." Tufts University Global Development and Environment Institute Working Paper.

Atreya, A., and J. Czajkowski. (2019). "Graduated Flood Risks and Property Prices in Galveston County." Real Estate Economics 47(3): 807-844.

Atreya, A., and S. Ferreira. 2015. "Seeing Is Believing? Evidence from Property Prices in Inundated Areas." Risk Analysis 35: 828-848.

Atreya, A., S. Ferreira, and W. Kriesel. 2013. "Forgetting the Flood? An Analysis of the Flood Risk Discount over Time." Land Economics 89: 577-596.

Bakkensen, L. A., and L. Barrage. 2018. "Flood Risk Belief Heterogeneity and Coastal Home Price Dynamics: Going Under Water?" National Bureau of Economic Research Technical Report.

Baldauf, M., L. Garlappi, and C. Yannelis, 2020. “Does Climate Change Affect Real Estate Prices? Only If You Believe In It." The Review of Financial Studies 33(3): 1256-1295.

Bernstein, A., M. T. Gustafson, and R. Lewis. 2020. "Disaster on the Horizon: The Price Effect of Sea Level Rise." Journal of Financial Economics 134(2): 253-27.

Billings, S. B., E. Gallagher, and L. Ricketts. 2021. "Let the Rich Be Flooded: The Distribution of Financial Aid and Distress after Hurricane Harvey." University of Colorado Boulder Working Paper.

Bin, O., and C. Landry. 2013. "Changes in Implicit Flood Risk Premiums: Empirical Evidence from the Housing Market." Journal of Environmental Economics and Management 65: 361-376.

Brainard, L., 2021. "The Role of Financial Institutions in Tackling the Challenges of Climate Change," at the 2021 IIF U.S. Climate Finance Summit: Financing a Pro Growth Pro Markets Transition to a Sustainable, Low-Carbon Economy, hosted by the Institute of International Finance, Washington, D.C., https://www.federalreserve.gov/newsevents/speech/brainard20210218a.htm.

Brannon, I., and A. Blask, 2017. "Reforming the National Flood Insurance Program Towards Private Flood Insurance." Cato Institute. Policy Analysis, n. 817.

Burke, M., S. M. Hsiang, and E. Miguel. (2015). "Global Non-linear Effect of Temperature on Economic Production." Nature 527: 235-239.

Chavaz, M. 2016. “Dis-integrating Credit Markets: Diversification, Securitization, and Lending in a Recovery." Bank of England Working Paper 617. 
Cheney, J. S., 2006. "The Role of Electronic Payments in Disaster Recovery: Providing More Than Convenience." Payment Cards Center Conference Summary, Federal Reserve Bank of Philadelphia.

Cheney, J. S., and S. L. W. Rhine, 2006. "How Effective Were the Financial Safety Nets in the Aftermath of Katrina?" Payment Cards Center Discussion Paper, Federal Reserve Bank of Philadelphia.

Chivers, J., and N. E. Flores. 2002. "Market Failure in Information: The National Flood Insurance Program." Land Economics 78(4): 515-521.

Cohen, J. P., J. Barr, and E. Kim. 2021. "Storm Surges, Informational Shocks, and the Price of Urban Real Estate: An Application to the Case of Hurricane Sandy." Regional Science and Urban Economics 90.

Cortés, K. R. 2014. "Rebuilding After Disaster Strikes: How Local Lenders Aid in the Recovery." Federal Reserve Bank of Cleveland Working Paper 14-28.

Cortés, K. R., and P. E. Strahan. 2017. "Tracing Out Capital Flows: How Financially Integrated Banks Respond to Natural Disasters." Journal of Financial Economics 125, 182-199.

Dehring, C. A., W. D. Lastrapes, D. L. Eckles, and M. J. Browne, 2014. “Does National Flood Insurance Program Participation Induce Housing Development?" Journal of Risk and Insurance 86(4): 835-859.

Deryugina, T. 2017. "The Fiscal Cost of Hurricanes: Disaster Aid versus Social Insurance." American Economic Journal: Economic Policy 2017, 9(3): 168-198.

Deryugina, T., L. Kawano, and S. Levitt. 2018. "The Economic Impact of Hurricane Katrina on Its Victims: Evidence from Individual Tax Returns." American Economic Journal: Applied Economics 10(2): 202-233.

Dillon-Merrilly, R. L., L. Gez, and P. Getex. 2018. "Natural Disasters and Housing Markets. The Tenure Choice Channel." Georgetown University Working Paper.

Engle III, R. F., S. Giglio, B. T. Kelly, H. Lee, and J. Stroebel. 2019. "Hedging Climate Change News." National Bureau of Economic Research Working Paper 25734.

Fang, L., L. Li, and A. Yavas. 2020. "The Impact of Distant Hurricane on Local Housing Markets." Florida International University Working Paper.

Farrell, D., and F. Greig. (2018). "Weathering the Storm: The Financial Impacts of Hurricanes Harvey and Irma on One Million Households." JPMorgan Chase Institute.

Gallagher, J., and D. Hartley. 2017. "Household Finance After a Natural Disaster: The Case of Hurricane Katrina." American Economic Journal: Economic Policy 9(3): 199-228.

Garmaise, M. J., and T. J. Moskowitz. 2009. "Catastrophic Risk and Credit Markets." The Journal of Finance LXIV(2).

Gibson, M., J. T. Mullins, and A. Hill. 2019. "Climate Risk and Beliefs: Evidence from New York Floodplains." Williams College Working Paper.

Groen, J. A., M. J. Kutzbach, and A. E. Polivka. "Storms and Jobs: The Effect of Hurricanes on Individuals' Employment and Earnings over the Long Term." Center for Economic Studies 1521R. 
Hansen, J., R. Ruedy, M. Sato, and K. Lo (2010). "Global Surface Temperature Change." Review of Geophysics 48.

Harrison, D., G. Smersh, and A. Schwartz. 2001. "Environmental Determinates of Housing Prices: The Impact of Flood Zone Status." The Journal of Real Estate Research 21: 3-20.

Hilmi, N., N. Theux-Lowen, and M. B. C. Pinochet. (2020). "Ocean-Related Impacts of Climate Change on Economy." Life Below Water 1-12.

Hino, M., and M. Burke. (2020). "Does Information About Climate Risk Affect Property Values." National Bureau of Economic Research Working Paper. http://www.nber.org/papers/w26807.

Horsch, A., and S. Richter. 2017. "Climate Change Driving Financial Innovation: The Case of Green Bonds." The Journal of Structured Finance 23(1), 79-90.

Issler, P., R. Stanton, C. Vergara-Alert, and N. Wallace. 2020. "Mortgage Markets with ClimateChange Risk: Evidence from Wildfires in California." University of California, Berkeley, Working Paper.

JPMorgan Chase and Co. 2018. "Weathering the Storm. The Financial Impacts of Hurricanes Harvey and Irma on One Million Households."

https://www.jpmorganchase.com/institute/research/cities-local-communities/reportweathering-the-storm.

Kahn, M. E., and A. Ouazad. 2019. "Mortgage Finance in the Face of Rising Climate Risk." National Bureau of Economic Research Working Paper 26322.

Keys, B. J., and P. Mulder. 2020. "Neglected No More: Housing Markets, Mortgage Lending and Sea Level Rise." National Bureau of Economic Research Working Paper 27930.

Knowles, S. G., and H. C. Kunreuther. 2014. "Troubled Waters: The National Flood Insurance Program in Historical Perspective." The Journal of Policy History 26:3, 2014.

Kousky, C., M. Palim, and Y. Pan. 2020. "Flood Damage and Mortgage Credit Risk: A Case Study of Hurricane Harvey." Journal of Housing Research 29(S1), S86-S120.

Lambert, F. F. Noth, and U. C. Schüwer. 2019. "How Do Banks React to Catastrophic Events? Evidence from Hurricane Katrina." Review of Finance 23(1): 75-116.

Michel-Kerjan, E.O. 2010. "Catastrophe Economics: The National Flood Insurance Program." Journal of Economic Perspectives 24(4): 165-186.

Morse, A. 2011. "Payday Lenders: Heroes or Villains?" Journal of Financial Economics 102(1): 28-44.

Munich RE, 2018. "Risks Posed by Natural Disasters." https://www.munichre.com/en/risks/natural-disasters-losses-are-trending-upwards.html.

Murfin, J., and M. Spiegel. 2020. "Is the Risk of Sea Level Rise Capitalized in Residential Real Estate?" The Review of Financial Studies 33(3).

NASA Earth Observatory (2017). “How Is Today's Warming Different from the Past?" https://earthobservatory.nasa.gov/Features/GlobalWarming/page3.php.

NOAA (2017). “Global Climate Change Indicators." https://www.ncdc.noaa.gov/monitoringreferences/faq/indicators.php. 
Ortega, F., and S. Taspinar. 2018. "Rising Sea Levels and Sinking Property Values: Hurricane Sandy and New York's Housing Market." Journal of Urban Economics 106: 81-100.

Peralta, A., and J. B. Scott, 2019. "Moving to Flood Plains: The Unintended Consequences of the National Flood Insurance Program on Population Flows." Louisiana State University Working Paper.

Ratcliffe, C., W. Congdon, D. Teles, A. Stanczyk, and C. Martin. 2020. "From Bad to Worse: Natural Disasters and Financial Health." Journal of Housing Research 29(sup1): S25-S53.

Ratnadiwakara, D., and B. Venugopal. 2020. "Do Areas Affected by Flood Disasters Attract Lower Income and Less Creditworthy Homeowners?" Journal of Housing Research 29(S1): S121-S143.

Roth Tran, R.B., and T. L. Sheldon. 2019. "Same Storm, Different Disasters: Consumer Credit Access, Income Inequality, and Natural Disaster Recovery." Board of Governors of the Federal Reserve System Working Paper.

Sheldon, T. L., M. Gall, and L. Collins. 2017. "Disaster Response, Public Safety, and Community: The Hidden Costs of School Closures." Department of Economics, Darla Moore School of Business, University of South Carolina Working Paper.

UN IPCC (2021). "Summary for Policymakers." in Climate Change 2021, Sixth Assessment Report of the Intergovernmental Panel on Climate Change, Cambridge University Press, Cambridge, UK. https://www.ipcc.ch/report/ar6/wg1/.

van der Wiel, K., S. B. Kapnick, G. J. van Oldenborgh, K. Whan, S. Philip, G. A. Vecchi, R. K. Singh, J. Arrighi, and H. Cullen. 2017. "Rapid Attribution of the August 2016 Flood-Inducing Extreme Precipitation in South Louisiana to Climate Change." Hydrology and Earth System Science 21: 897-921.

Vigdor, J. 2008. "The Economic Aftermath of Hurricane Katrina." Journal of Economic Perspectives 22(4), Fall 2008: 135-154.

Zhang, L. 2016. "Flood Hazards Impact on Neighborhood House Prices: A Spatial Quantile Regression Analysis." Regional Science and Urban Economics 60(2016): 12-19. 


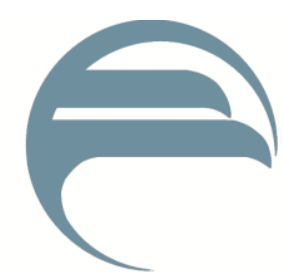

FEDERAL Reserve BANK of PHILADELPHiA

Consumer Finance Institute Discussion Paper Series

http://www.philadelphiafed.org/consumer-finance-institute 